\title{
PREFACE
}

\section{The Face in the Flower}

\author{
Thou still unravished bride of quietness! \\ Thou foster-child of Silence and slow Time, \\ Sylvan historian, who canst thus express \\ A flowery tale more sweetly than our rhyme: \\ What leaf-fringed legend haunts about thy shape \\ Of deities or mortals, or of both, \\ In Tempe or the dales of Arcady? \\ —JOHn keats, "Ode on a Grecian Urn"
}

Is it better for gardeners, professional horticulturists, conservationists, and naturalists to learn the common names of plants or their scientific names? Readers of my past books know I emphasize the importance of common names, as they offer a royal road to world folklore and economic botany. The more common names a plant receives, both regionally and in different languages, the easier it is to discern how different cultures have viewed it and used it over time. Perennial herbs sold under the name of monkshood or troll's hat reflect nothing more than a whimsical interpretation of a flower's shape. When the same plants are called wolfsbane or badger's bane, they take us back to darker times when roots were rendered to make poison baits to lure and kill wild animals.

Unfortunately, when common names are employed exclusively to make identifications, we are often forced to contend with three equally frustrating problems. First, many plants lack common names, or their common names were lost. It is estimated that there are more than a quarter of a million plant species on this planet. Natural variation defies human imagination and verbal creativity. Traditional cultures often fail to name plants that have no immediate use. Thousands of wild orchid species cling to the limbs of trees from southern Mexico to Panama, for example, but local people, if questioned, are likely to refer to almost all of them as parasitas (parasites), or to their flowers as conchitas (little shells). The famous ethnobotanist and 
conservationist Paul Cox warns that as "weedy, European languages" (especially English and Spanish) infiltrate the few remaining indigenous cultures around the world, common names of plants are lost after a single generation. This is a tragedy, as the aboriginal name of a tree often tells you its specific use as a tool, medicine, or recreational drug.

The second problem is that common names are too imprecise for identification purposes because very different species often have the exact same name. Some of us make bad choices when we try to use a common name to match up a source of bulbs or seeds in insufficiently illustrated catalogs. For example, in the United States, Sweet William is a name given to a popular bedding plant (Dianthus barbatus), but it is also applied to some native Pblox species now in cultivation. Moreover, the same common name is often applied to many closely related plants, making it harder to select the one you really want. Do you like basil in pesto and tomato sauces? There are at least a 150 wild species of plants called basil in English and an additional four or five of these species are domesticated plants in cultivation. Their foliage produces essential oils, but fragrances vary in composition and concentration from species to species. One of these herbs (Ocimum basilium) tastes best on a pizza, whereas another serves in Hindu rituals ( $O$. sanctum). If a woman is offered basil (O. selloi) while visiting Uruguay, it may be an unsubtle hint that she needs a traditional remedy to curb her fertility, not an invitation to dinner.

That leads to the third problem. Common names do not respect natural alliances based on shared genes. Rockroses (Cistus spp.), the rose bay (Nerium oleander), the guelder rose (Viburnum opulus), native roses (Boronia spp.), and the rose pink (Sabatia angularis) all share one thing in common. None of them belong to the rose family (Rosaceae). In contrast, such differentsounding names as old goose, Noah's Ark, moccasin flower, sparrow's egg, flor de pelicano, and hare's lip are applied to thirteen closely related species of North American orchids in the genus Cypripedium.

You cannot assemble a collection of closely related plants if you do not know the classification rules and terminology that assure you that these plants belong to the same "family tree." You cannot protect any endangered species until everyone agrees that all remaining small, isolated populations are composed of the same thing.

I apologize for opening with a trick question. The honest answer is that we need both common and scientific names if we want to verify scientific research, keep a greenhouse for business or pleasure, design herb gardens, enjoy walks in the woods, participate in eco-tourism, and vote on pressing 
environmental issues. Many English-speaking residents of Britain, South Africa, Australia, and New Zealand store lots of common and scientific names in their memories, much as we keep shovels and rakes in garden sheds. You cannot do the job right without the right tool. Many Australians have modified scientific names to fit the vernacular. They take you for a nice walk in the bush, introducing you to their "eucalypts, banksias, and acacias" before they remember to tell you that these plants are called gum trees (Eucalyptus spp.), native honeysuckles (Banksia spp.), and wattles (Acacia spp.).

Americans tend to resist scientific names, employing much the same passive-aggressive technique that we have used so successfully to resist national implementation of the metric system. I have written elsewhere (The Rose's Kiss, 2002) how public schools avoid teaching the basics of botany from primary grades through high school biology courses. Well, scientific names are one of the first tools every instructor needs in order to teach the overlapping branches of the life sciences. When classes about the composition and use of scientific names are replaced with lessons about how to recycle trash, plant trees, and turn off the faucet while brushing one's teeth, we are replacing access to a scientific tool with lessons in environmental stewardship. Both subjects are important, but, as they have different goals, environmental protocols are never adequate replacements for the principles of biology. Substitute a different topic for science, and you deaden youthful interests in plant conservation and future careers in intense but objective research. I teach four plant science courses to biology majors at Saint Louis University. Every semester someone whines, "Do we have to know all these names?"

Of course, it is my responsibility to make classification and the translations of scientific names relevant and entertaining, but I have never been alone. Every five or six years some botanist or professional horticulturist writes a book meant to explain the ground rules and attempts to lead home gardeners through the jungle of plant names. Some would nominate How Plants Get Their Names, by L. H. Bailey, as the short and sweet granddaddy of such reference books. Many more have followed and will continue to follow. I think these well-written books have limited impact, because most are conceived as lexicons or dictionaries, turning the definitions of scientific names into disconnected sound bites. We prefer narratives and want to be convinced that there is an overarching story behind centuries of botanical classification. One of Howard Ensign Evans's last books, Pioneer Naturalists (1993), explained why so many American plants and animals were named after explorers and collectors. Evans offered brief biographies to show why these men and women deserved the honor of having a genus or species 
named after them. The author showed that Lewisia (bitterroot) and Clarkia (ragged robin, farewell-to-spring) celebrate the expedition of Meriwether Lewis and William Clark.

That makes a fine start, but will enthusiasm for scientific names increase if the stories take on a fantastic twist? One aspect of Western civilization has not changed in more than two millennia. We still prefer stories about potent drugs, bizarre sex, and violent crimes. Most of us still enjoy a good yarn featuring drugs made from plants. Unfortunately, it is hard to turn floral sex or the smothering violence of vines competing for sunlight into salacious gossip (heaven knows, I've tried; see my Natural Affairs: A Botanist Looks at the Attachments between Plants and People [New York: Villard Books, 1993] and Wily Violets and Underground Orchids: Revelations of a Botanist [1989; repr., Chicago: University of Chicago Press, 2003]). Fortunately, we need only revisit the Greco-Roman myths to locate the archetypes of perversity and outrageous cruelty. Western art and science share the same fascination with classical celebrities. Every century, the protagonists in these myths are invited to repeat their unnatural acts in new poems, novels, dramas, films, paintings, and sculptures. Likewise, biologists have used them as sources of scientific names since the second half of the eighteenth century. I encountered them in college courses in botany but awarded them little significance for almost three decades. What changed my attitude?

In 1997, the Stanley Smith Horticultural Society gave me a grant to study the breeding system of mandrakes (Mandragora officinarum) in northern Israel. This wayside weed bears fragrant berries, used to scent a novel liqueur. Investigation of the natural sex life of the mandrake ultimately helped determine how the grower might increase fruit yield. My Israeli mentor, Dr. Amots Dafni at the University of Haifa, was determined that my weekends would not pass exclusively in muddy fields kneeling over to pollinate mandrake flowers. Amots is a proud sabra, and he was determined I would see wonders beyond the Kishon valley. Please pardon the classical allusion, but this book's odyssey began precisely on the first of January 1998 when Amots and his daughter took me to the archaeological dig, or Tel, at Bet She'an. Several civilizations settled there over thousands of years, but it was now part of a long-term project to excavate and reconstruct the town established by conquering Romans. We walked by resurrected sections of an amphitheater, bathhouse, goldsmith shop, and a temple to the goddess Nysa. A sign said she was a nursemaid of Bacchus. I thought I knew my Greco-Roman mythology rather well, but who was Nysa? How did she come to nurture the god of wine, and why did her name sound 
so ... well, botanical? It brought back odd memories of a stroll in a swamp in Louisiana.

Upon my return to St. Louis I purchased an old paperback copy of the Dictionary of Classical Mythology by J. E. Zimmerman (1971). This gave me a proper introduction to Nysa, or Nyssa (as her name is most often spelled in English). However, like most dictionaries, it did not give me a full story, so I treated myself to both volumes of The Greek Mytbs, by Robert Graves (1957). Botanical lexicons cleared up the last mystery. Nyssa is the name of a genus that the Swedish plant taxonomist Carl von Linnaeus gave to the genus of tupelos. Nyssa aquatica was the sour gum tupelo I saw, years earlier, in a park outside New Orleans. At that time the tree limbs cradled local snakes, not baby deities, and the image of sleeping cottonmouths coiled around branches was hard to forget.

It did not stop there. Leafing through the lexicons, I discovered that my own garden harbored gods, goddesses, nymphs, and heroes. Smilax continued to disdain the mortal boy, Crocus, as she grew in backyard shade while he needed the sunny front rock garden. Paeonius dispensed flowers instead of medical remedies. Iris and Hermes waited to take messages from the King of the Gods, but he was too busy dropping walnuts on my roof. I just had to share this information with others, but how? I considered writing another specialized dictionary or lexicon, to follow a noble tradition, but then I ran into Dr. Ghillean Prance, who was visiting the Missouri Botanical Gardens. Dr. Prance had spent years working at the Bronx Botanical Gardens (I was one of his technicians back in 1977) before he became the director of Kew Gardens in England. He liked the idea of the book but said that most Americans were unfamiliar with the classical myths so I must retell the stories.

Showing the connection between false gods and real plants seemed entertaining and innovative. After all, most books of Greek mythology are presented as pseudohistories. They start with creation tales of Mother Earth and her Titan children; pass on to Zeus, his Olympian family, and the deeds of their half-mortal bastards; and then finish with the Trojan War and the wanderings of Odysseus. I learned that some botanists honored characters in the most obscure myths. It gave me confidence that even the residents of the British Commonwealth might also be unfamiliar with Nyssa.

Because stories are superior to glossaries, it seemed logical to borrow the format preferred by Robert Graves. Tell each myth separately, but organize them to show how they interconnect with each other. Follow each tale with itemized interpretations. However, readers are warned that I do not 
subscribe to any of Graves's theories about the origins of Mediterranean religions. The history of the worship of an immortal, triple-faced goddess and her more vulnerable sons is best left to the pertinent criticisms of serious scholars. I prefer to parallel each myth with more relevant commentary on plants named after the protagonists and how the plot line enriched the language of botany. It is a modest goal. Owing to space limitations, the names discussed and explained must be limited to seed plants. Someone else can have the pleasure of introducing the myths that inspired the scientific names of other members of the plant kingdom (mosses, liverworts, ferns, and their allies), as well as the associated kingdoms of fungi and algae.

Even if I cannot convince you to use scientific names on a regular basis, perhaps this book will improve social events. The quickest way to kill party conversation in Missouri these days is for someone to say, "Gardening is such a challenge in the Midwest." Silence falls as we stare into our cocktail glasses, remembering bulbs eaten by squirrels and bills paid to remove trees toppled by tornados. Discussing plants named after centaurs sounds far more amusing and fitting (especially over wine). Sometimes the most magnificent garden is the one you keep in your head. 